\title{
Effect of Nitrogen Fertilizer Rates and Intra-row Spacing on Yield and Yield Components of 'Improved Huruta' Shallot Variety (Allium cepa var.ascalonicum) at Haramaya, Eastern Ethiopia
}

\author{
Tsegaye Shimelis $^{1, a, *}, K^{2}$ ebede Woldetsadik ${ }^{1, b}$, Wassu Mohammed ${ }^{1, \mathrm{c}}$ \\ ${ }^{1}$ School of Plant Sciences, Haramaya University, Dire Dawa, Ethiopia \\ *Corresponding author
}

\section{A R T I C L I N F O A B S T R A C T}

Research Article

Agronomic practices for the newly released shallot variety have not been conducted in Eastern Ethiopia. To assess the effect of nitrogen fertilizer rates and intra-row spacing, a field experiment was conducted in 2017 which consisted of seven rates of nitrogen $(0,25,50,75,100,125$ and 150 $\left.\mathrm{kg} \mathrm{N} \mathrm{ha}^{-1}\right)$ and three intra-row spacing $(7.5,10$ and $12.5 \mathrm{~cm})$ in factorial combination and it was laid

Received : 30/05/2020 Accepted : $11 / 10 / 2020$ out in a RCBD with three replications. Results of the analysis revealed that all bulb yield and yield components of the variety were highly significantly influenced by the main effects of nitrogen fertilizer and intra-row spacing. Moreover, the interaction of nitrogen fertilizer and intra-row spacing significantly influenced days to maturity, plant height, and average bulb weight and bulb dry matter. The application of $125 \mathrm{~kg} \mathrm{~N} \mathrm{ha}^{-1}$ gave high total and marketable bulb yield advantage of $32.45 \%\left(13.89 \mathrm{t} \mathrm{ha}^{-1}\right)$ and $40.8 \%\left(15.47 \mathrm{t} \mathrm{ha}^{-1}\right)$, respectively over the control. Plants spaced at 7.5

Keywords:

Nitrogen $\mathrm{cm}$ had total and marketable bulb yield advantage of 35.94\% $\left(14.54 \mathrm{t} \mathrm{ha}^{-1}\right)$ and $32.83 \%\left(12.42 \mathrm{t} \mathrm{ha}^{-1}\right)$,

Intra row

Bulb diameter

Dry matter

Marketable bulb yield respectively over plants spaced at $12.5 \mathrm{~cm}$. Therefore, intra-row spacing of $7.5 \mathrm{~cm}$ with the application of $125 \mathrm{~kg} \mathrm{~N} \mathrm{ha}^{-1}$ is used for optimum yield in the study area although further research should be needed to come up with conclusive recommendation.

\section{Introduction}

Allium cepa as bulb onion and/or shallot is probably grown in all countries of tropical Africa including Ethiopia (Grubben and Denton, 2004). Shallot (Allium cepa var. ascalonicum) is an onion like plant that is originated from Western Asia. It belongs to the Alliaceae family which includes other plants such as chives, leeks, garlic and onions. It is very similar to common onion; unlike the common onion, which has a large single bulb, it produces clusters of several bulb splits (2 to 20 bulb lets) (Currah and Proctor, 1990; Brewster, 1994). Although bulb onions are widely grown in the tropics, farmers prefer shallots for their better tolerance to disease, shorter growth cycle, and drought stresses and longer storage life than the common onion and for their distinct flavor that persists after cooking (Currah and Proctor, 1990; Kebede, 2003).

Fertilization is one of the determining factors in an effort to increase crop yields. To be able to grow and to produce optimally, shallot plants need sufficient and balanced amount of nitrogen $(\mathrm{N})$, phosphorus $(\mathrm{P})$, potassium $(\mathrm{K})$ as well as other nutrients (Purba, 2014). In general, application of $\mathrm{N}, \mathrm{P}$ and $\mathrm{K}$ fertilizer can increase the growth and bulb yield of shallots (Sigh et al., 2000). Mineral fertilizers play an important role of onion/shallot plant growth and productivity. Many investigators reported that the vegetative growth of onion plants and minerals uptake was increased with increasing the level of NPK fertilizers (Subbo, 1988).

Nutrient requirement of Onion and/or shallot depends on environment of a particular locality or soil type. Split application of $92 \mathrm{~kg} \mathrm{~N} \mathrm{ha}^{-1}$ was found adequate for dry bulb production in upper awash region. Farmers in the rift valley apply $200 \mathrm{~kg} \mathrm{ha}^{-1}$ DAP and $100 \mathrm{~kg} \mathrm{ha}^{-1}$ Urea and the Horticultural State Enterprise apply about twice the above concentration with expectation of high yield. However, the best combination levels for a particular locality or soil type have to be determined for economic production of dry bulb (Dessalegn and Aklilu, 2003).

Plant population is also important in onion production since it has an influence on growth, yield and quality of onion bulbs (Brewster, 1994). Optimums inter and intra- 
row spacing varies with soil fertility status, soil moisture, the nature of the crop and degree of weed infestation (Singh et al., 1997). Different agronomic practices and growing environments are known to influence yield and quality of dry bulbs. Spacing has effect on different varieties as their root and leaf growth habits differ.

The intra-row spacing recommended for onion should be different from shallot because it produces clusters of several bulb splits. Shallots are commonly planted at intrarow spacing between 12 to $15 \mathrm{~cm}$ when propagated by bulblets (Williams et al., 1991). Shallots planted at 15 to $20 \mathrm{~cm}$ between the bulbs have also been reported to give highest marketable yield (Bodnar, 2010). Devi and Anal (2008) recommended $10 \mathrm{~cm}$ as optimum intra-row spacing for shallot for higher marketable yield. Thus, internationally; optimum intra-row spacing for shallot is contentious and is dependent on environmental condition and type of cultivar used. Some farmers use the intra-row spacing recommended for onion despite the fact that shallots produce small multiple bulbs per plant unlike onion and thus need totally different intra-row spacing (Dereje et al., 2012).

Absence of Improved shallot varieties capable to produce seed in the country including the study area was a bottleneck to its production and productivity. Seed production from shallot variety is one of the most important challenges in horticultural crops and the researchers in horticulture are thriving to produce seed from this crop throughout the world. Accordingly, the researchers in Haramaya University were capable to produce seeds from this crop successfully with uninterrupted efforts made for more than a decade. As a result a seed producing line derived from 'Huruta shallot variety was released in 2017. This is believed to solve the problems in shallot production by alleviating the shortcomings of using bulbs as a planting material, which is needed in large quantity, has short shelf-life, and could be source of inoculums for diseases and pests. With the production of seed from this variety through seed to bulb method, researchers have a chance to improve the bulb yield of the variety.

Therefore, it was felt necessary to develop packages to recommend this variety for cultivation in eastern Ethiopia. Hence, this research was initiated to assess the effect of nitrogen fertilizers rate and intra-row spacing on yield and yield components of Improved 'Huruta' shallot variety.

\section{Materials and Methods}

\section{Description of the Experimental Site}

The field experiment was conducted in 2017 from July to December at Haramaya University Raree research site. Haramaya University is located $25 \mathrm{~km}$ Northwest of Harar town. Haramaya University Raree Research farm is located at 2020 meters above sea level, $9^{\circ} 41^{\prime \prime} \mathrm{N}$ latitude and $42^{\circ} 03^{\prime \prime} \mathrm{E}$ longitude. The area receives an annual rainfall of $760 \mathrm{~mm}$ with bimodal rainfall pattern and average maximum and minimum temperatures of $23.4^{\circ} \mathrm{C}$ and $8.25^{\circ} \mathrm{C}$, respectively. The area has a bimodal rainfall distribution and is representative of a sub-humid mid altitude agro-climatic zone. The short rainy season extends from March to April and constitutes about 25\% of the annual rainfall where as the long rainy season extends from
June to October and accounts for about $45 \%$ of the total rainfall (Belay et al., 1998). The soil of the area is characteristically light sandy loam soil with $\mathrm{pH}$ of 8.0 (Burga et al., 2014).

\section{Description of Experimental Materials \\ Planting Material}

The seed produced from improved 'Huruta' shallot variety was used. The variety was released by Haramaya University in 2017. The variety has an average seed yield of 500 to $600 \mathrm{~kg} \mathrm{ha}^{-1}$. Improved Huruta shallot variety had an advantage of an increment in both marketable bulb weight $(10.01 \%)$ and bulb yield $(9.66 \%)$ than commercial hybrid onion cultivar (Kelafo) which is popular in Eastern Ethiopia. Moreover, the variety has many other bulb and seed quality traits than commercial onion varieties (Mohammed et al., 2017). The detailed description of the varieties is given in the Table 1.

Table 1. Description of agronomic characters of Improved Huruta shallot variety*

\begin{tabular}{l|c}
\hline \multicolumn{1}{c|}{ Characteristics } & $\begin{array}{c}\text { Improved Huruta } \\
\text { shallot variety }\end{array}$ \\
\hline Adaptation area and management & Altitudes** \\
Average bulb maturity & 134 days \\
Plant height $(\mathrm{cm})$ & 58.69 \\
Leaf length $(\mathrm{cm})$ & 47.42 \\
Number of leaves & 9 \\
Bulb color & Deep red \\
Marketable bulb weight $(\mathrm{g})$ & 71.97 \\
Proportion of unmarketable bulbs $(\%)$ & 18.5 \\
Marketable bulb yield $\left(\mathrm{t}\right.$ ha $\left.{ }^{-1}\right)$ & 36.74 \\
Total bulb yield (t ha $\left.{ }^{-1}\right)$ & 45.14 \\
Year of release & 2017 \\
\hline
\end{tabular}

*Source: Haramaya University Vegetable Research Program (2017), **Medium to high altitudes of eastern Ethiopia (1600-2800 meters above sea level)

\section{Fertilizer Material used}

The sources of the fertilizers were urea $\left(\mathrm{CO}\left[\mathrm{NH}_{2}\right]_{2}\right)$ $(46 \% \mathrm{~N})$ and Triple Super Phosphate, $\left(\mathrm{Ca}\left[\mathrm{H}_{2} \mathrm{PO}_{4}\right]_{2}\right)$, which constitutes about $46 \% \mathrm{P}_{2} \mathrm{O}_{5}$ for supplying nitrogen and phosphorus respectively were used.

\section{Treatments and Experimental Design}

The treatments consisted of seven levels of Nitrogen $(0$, $25,50,75,100,125$ and $150 \mathrm{kgha}^{-1}$ ) and three levels of intra-spacing $(7.5,10$ and $12.5 \mathrm{~cm})$ which were laid out as a randomized complete block design (RCBD) with three replications. Thus, there were 21 treatment combinations, which account for 63 experimental units. Each treatment was assigned to the plots randomly. Improved Huruta Shallot seedlings were planted in double row spacing. The size of each plot was $2.4 \mathrm{~m} \times 2.25 \mathrm{~m}\left(5.4 \mathrm{~m}^{2}\right.$ accommodating ten rows (five double rows planted on 40 $\mathrm{cm}$ wide ridges) with 25,19 and 15 plants per row for the intra-row spacing of 7.5, 10 and $12.5 \mathrm{~cm}$, respectively. The recommended inter-row spacing of $20 \mathrm{~cm}$ on the ridge (Dessalegn and Aklilu, 2003) was equally maintained for all plots. A distance of $1.5 \mathrm{~m}$ was maintained between the blocks whereas the space between each plot within a block was $1 \mathrm{~m}$. The outer double rows at both sides of the plot and one plant at both ends of the rows were considered as 
border plants to avoid edge effects. Plants in the middle six rows were used to determine bulb yield per plot which was converted to $\mathrm{t} \mathrm{ha}^{-1}$.

\section{Experimental Procedures}

The seeds of Improved Huruta shallot variety were obtained from horticulture section of Haramaya University. Seeds were collected and stored for about one month and prepared for sowing on a nursery on a well prepared seed bed. Watering and weeding of seedling at nursery were carried out manually when needed. Transplanting the seedlings into the experimental plots was done after 45 days of sowing. Before transplanting seedlings, the experimental field was plowed, pulverized and leveled well. Each treatment combination was assigned randomly to experimental units within a block. The seedlings were transplanted at $12-15 \mathrm{~cm}$ height, about 3 - 4 true leaves stage, by carefully uprooting from nursery bed. One day before transplanting of seedlings, the nursery was irrigated to facilitate the uprooting and subsequent good field establishment of seedlings. Healthy, normal and uniform seedlings grown at the center of seedbeds were transplanted. Re-planting was carried out within one week to replace those seedlings which were damaged and failed to establish. Ten sample plants in the middle six rows were used for recording data. Nitrogen fertilizer was side dressed at the specified rates in three splits $\left(1 / 4^{\text {th }}\right.$ at transplanting, $1 / 2$ at active stage of vegetative growth, and $1 / 4^{\text {th }}$ at the start of bulbing) (EIAR, 2004). Phosphorus in the form of TSP was applied to all plots equally at planting time as a single application $\left(92 \mathrm{~kg} \quad \mathrm{P}_{2} \mathrm{O}_{5} \mathrm{ha}^{-1}\right)$ and incorporated to the soil on the prepared ridges in bands. At the end of the rainy season, supplemental irrigation was carried out using furrow and provided uniformly to all plots. Other recommended agronomic practices like, weeding, crop protection, etc., were kept uniform for all treatments. When $70 \%$ tops leaves senesced or fall down, bulbs were harvested and used for determining bulb yield and yield related traits (EIAR, 2004). The harvested bulbs were cured under shade (screen house) for a week before topping.

\section{Data Collected}

Data on growth, bulb yield and yield component of Improved Huruta shallot variety were recorded from six central rows. While data on days to maturity were recorded on the basis of whole plot as per the procedures mentioned as follows.

\section{Phenology and Growth Parameters}

Days to maturity was recorded as the actual number of days from the date of transplanting to the time when $70 \%$ of plants in each plot showed neck fall or attained physiological maturity (EIAR, 2004). Leaf length (cm) was recorded as the average leaf length of the longest leaves of sampled plants at maturity. This was measured from the sheath to tip of the longest leaf from ten leaves of the representative plants. Likewise, Number of leaves/plant was counted from 10 randomly selected plants. Plant height $(\mathrm{cm})$ for 10 randomly selected shallots per plot was measured using ruler. It was measured from the ground to the tip of the leaves at maturity.

\section{Yield and Yield Components}

Bulb diameter $(\mathrm{cm})$ for 10 randomly selected shallots per plot was measured using a digital caliper. It was measured at the maximum wider portion of matured bulbs after curing. Likewise, Bulb length $(\mathrm{cm})$ was measured as the vertical average length of the matured bulb of sampled plants which was measured with a digital caliper. Bulb dry matter (\%) of five bulbs of sampled plants were chopped in to small piece with the help of steel knife mixed thoroughly and samples of $100 \mathrm{~g}$ was weighed and recorded as fresh weight. Each sample was placed in a paper bag and put in an oven at $65^{\circ} \mathrm{C}$ until constant dry weight was achieved and each sample was immediately weighed and recorded as dry matter of bulb.

Dry biomass yield $\left(\mathrm{g} \mathrm{plant}^{-1}\right)$ was recorded as the sum of dry weight of above ground parts and bulbs of sampled plants taken after oven drying to a constant weight. This was determined by summing up the shoot and bulb dry weights of sample plants. The average biological yield of sampled plants was calculated and recorded as dry biological yield per plant. On the same manner, Fresh biomass yield $\left(\mathrm{g} \mathrm{plant}^{-1}\right)$ was recorded as the sum of the fresh weight above ground parts and bulbs of sampled plants taken as soon as the crop was harvested at maturity. Then the average fresh biomass yield per plant was calculated and recorded.

Marketable bulb yield ( $\mathrm{t} \mathrm{ha} \mathrm{h}^{-1}$ ) was determined after discarding bulbs smaller than $3 \mathrm{~cm}$ in diameter; splitted, thick necked, rotten and discolored bulbs. Marketable fresh bulb yield was computed from the harvest of net plot. Accordingly, this parameter was determined from entire plants in the six central rows at the final harvest after curing. On the other hand, Unmarketable bulb yield ( $t$ ha $^{-}$ $\left.{ }^{1}\right)$ was determined by categorizing under sized $(<20 \mathrm{~g}$ or less than $3 \mathrm{~cm}$ in diameter), diseased, decayed, discolored, physiologically disordered such as thick-necked and split bulbs and weighing the bulbs, and expressing as unmarketable bulbs from the harvest of net plot area (Dessalegn and Aklilu, 2003). Total bulb yield ( $\mathrm{t} \mathrm{ha}^{-1}$ ) was calculated as summation of marketable and unmarketable bulb yield. Average bulb Weight (gm) for ten randomly selected shallots bulb was measured using sensitive balance after harvesting and curing.

\section{Data Analysis}

The data were subjected to analysis of variance (ANOVA) using the general linear model of GenStat $16^{\text {th }}$ edition statistical package. Treatment means that exhibited significance difference was separated using Duncan Multiple range test (DMRT) at 5\% level of significance.

\section{Results and Discussion}

\section{Phenology and Growth Parameters}

Days to Maturity

The result from the analysis of variance indicated those days to physiological maturity of Improved 'Huruta' shallot variety was significantly $(\mathrm{P}<0.05)$ affected by the interaction effect of intra-row spacing and nitrogen fertilizer rates. The days to physiological maturity of the Variety was also significantly $(\mathrm{P}<0.01)$ affected by main effect of fertilizer and intra-row spacing (Table 9). 
The days to maturity ranged between 117 and 141 days. Increasing the rate of nitrogen markedly delayed the days to maturity across the intra-row spacing. The Improved shallot grown at the higher rates of nitrogen and the wider intra-row spacing matured later than plants supplied with the lower rates of nitrogen and lower intra-row spacing (Table 2). Improved Huruta shallot plants required the highest number of days to reach physiological maturity when plants where supplied with $150 \mathrm{~kg} \mathrm{~N} \mathrm{ha}^{-1}$ and at the spacing of 12.5 and $10 \mathrm{~cm}$. Plants which did not receive fertilizer and spaced at $7.5 \mathrm{~cm}$ reached physiological maturity earlier than plants supplied with $150 \mathrm{~kg} \mathrm{~N} \mathrm{ha}^{-1}$ and spaced at $12.5 \mathrm{~cm}$ by about 24 days.

The prolonged maturity of Improved Huruta shallot at higher nitrogen rate and wider intra row spacing might be ascribed to less competition for light and nutrient in wider spacing, causing luxurious foliage growth and delayed bulb maturity. The delay in physiological maturity due to nitrogen fertilizer application is attributed to the delayed canopy growth in response to nitrogen rate which maintain physiological activity for an extended period and thereby continuing photosynthesis (Brewster, 1994; Marschner, 1995).

\section{Plant Height}

The result from the analysis of variance revealed significant $(\mathrm{P}<0.05)$ effect of interaction between nitrogen and intra-row spacing on height of Improved Huruta shallot variety (Table 9). Maximum plant height was recorded at the application rate of 125 and $150 \mathrm{~kg} \mathrm{~N}^{-1}$ with $12.5 \mathrm{~cm}$ intra row spacing. But, both application of Nitrogen rate at 125 and $150 \mathrm{Kg} \mathrm{N} \mathrm{ha}^{-1}$ combined with $12.5 \mathrm{~cm}$ intra row spacing did not show statistically significant $(\mathrm{P}<0.05)$ difference from each other (Table 2$)$.

The increase in height of Improved Huruta shallot at higher $\mathrm{N}$ rate and wider spacing might be due to more nutrient and adequate space favorable for their growth and development. This is because of the fact that nitrogen is mainly concerned with the vegetative growth of plants through cell division and elongation (Marchsner, 1995). Similarly, the shortest plant was registered from plants that didn't receive $\mathrm{N}$ fertilizer application combined with the closest spacing $(7.5 \mathrm{~cm})$. Thus, the shortest plant $(63.67 \mathrm{~cm})$ was observed from the plants that received $7.5 \mathrm{~cm}$ intrarow spacing combined with zero nitrogen rates (Table 2). This might be associated with more competition for resources that resulted in stunted growth. Similarly, Biru (2015) from study conducted at Jimma University reported that heights of shallot plants increased in response to increasing nitrogen rate and intra-row spacing where 150 $\mathrm{kg} \mathrm{ha}^{-1}$ and $20 \mathrm{~cm}$ spacing resulted in highly significant plant height of shallot.

\section{Leaf Number}

The main effect of nitrogen rate and intra row spacing had highly significant $(\mathrm{P}<0.01)$ influence number of leaves per plant of Improved Huruta shallot Variety. However, the interaction of the two factors did not significantly affect this parameter (Table 9). Increasing nitrogen rate significantly increased leaf number of Improved Huruta shallot variety. The maximum leaf number (10.27) was recorded at the application rate of $150 \mathrm{~kg} \mathrm{~N}^{-1}$ which was $45.26 \%$ higher than the lowest leaf number recorded from zero nitrogen application (Table 3). In line with the present result, Fikadu (2015) reported that nitrogen levels significantly increased the number of leaves per plant of shallot with the highest value obtained from $100 \mathrm{~kg} \mathrm{~N} \mathrm{ha}^{-1}$.

Regarding the main effect of intra row spacing, maximum leaf number (9.74) of Improved Huruta shallot was recorded at the widest intra-row spacing $(12.5 \mathrm{~cm})$. In contrast, plants with the lowest number of leaves (8.07) were recorded in response to the closest intra-row spacing $(7.5 \mathrm{~cm})$ (Table 3$)$. In agreement with this result, Sikder et al. (2010) showed that the maximum leaf numbers per plant of onion were recorded in response to wider plant spacing.

\section{Leaf length}

The result from Analysis of variance revealed that leaf length of Improved Huruta shallot was highly significantly $(\mathrm{P}<0.01)$ influenced by the main effects of both intra row spacing and nitrogen fertilizer rates. However, the interaction of the two factors did not significantly affect this parameter (Table 9). Irrespective of the intra-row spacing treatments, the longest leaf length $(56.22 \mathrm{~cm})$ of the plant was obtained by application of nitrogen at the rate of $150 \mathrm{~kg} \mathrm{ha}^{-1}$ which, however, was not statistically different from the application of $125 \mathrm{~kg} \mathrm{~N} \mathrm{ha}^{-1}$ (Table 3). The increment in height with the amount of applied $\mathrm{N}$ is because of the fact that nitrogen influences the vegetative growth of plants through cell division and elongation (Marschner, 1995). On the other hand, the shortest leaf length $(47.62 \mathrm{~cm})$ of Improved Huruta shallot variety was observed in the control plot which is statistically at par with the application of $25 \mathrm{~kg} \mathrm{~N} \mathrm{ha}^{-1}$. The result is also in accordance with Rao et al. (2013) who reported that higher nitrogen fertilization increased leaf length of onion.

Table 2. Interaction effect of Nitrogen fertilizer rates and intra row spacing on days to maturity and plant height of Improved Huruta shallot variety grown at Haramaya under rain fed and supplemental irrigation

\begin{tabular}{c|cccccc}
\hline \multirow{2}{*}{ Treatment } & \multicolumn{3}{c}{ Parameter } \\
\cline { 2 - 6 } & \multicolumn{3}{|c}{$\begin{array}{c}\text { Days to maturity (days) } \\
\text { Intra-row spacing }(\mathrm{cm})\end{array}$} \\
\hline N rate $\left(\mathrm{kg} \mathrm{ha}^{-1}\right)$ & 7.5 & 10 & 12.5 & \multicolumn{3}{c}{$\begin{array}{c}\text { Plant height }(\mathrm{cm}) \\
\text { Intra-row spacing }(\mathrm{cm})\end{array}$} \\
0 & $117.3^{\mathrm{l}}$ & $119.7^{\mathrm{k}}$ & $123.7^{\mathrm{j}}$ & $63.67^{\mathrm{l}}$ & $66.53^{\mathrm{jk}}$ & $69.13^{\mathrm{hi}}$ \\
25 & $118.7^{\mathrm{kl}}$ & $124.3^{\mathrm{ij}}$ & $126.0^{\mathrm{hi}}$ & $65.60^{\mathrm{k}}$ & $69.67^{\mathrm{h}}$ & $72.33^{\mathrm{g}}$ \\
50 & $120.0^{\mathrm{k}}$ & $127.3^{\mathrm{gh}}$ & $128.7^{\mathrm{fg}}$ & $67.20^{\mathrm{j}}$ & $72.13^{\mathrm{g}}$ & $75.20^{\mathrm{de}}$ \\
75 & $122.3^{\mathrm{j}}$ & $129.0^{\mathrm{fg}}$ & $131.7^{\mathrm{e}}$ & $67.93^{\mathrm{ij}}$ & $73.07^{\mathrm{fg}}$ & $76.47^{\mathrm{cd}}$ \\
100 & $124.3^{\mathrm{ij}}$ & $130.7^{\mathrm{ef}}$ & $134.0^{\mathrm{d}}$ & $69.00^{\mathrm{hi}}$ & $73.40^{\mathrm{fg}}$ & $77.60^{\mathrm{bc}}$ \\
125 & $130.3^{\mathrm{ef}}$ & $135.3^{\mathrm{cd}}$ & $138.7^{\mathrm{b}}$ & $69.33^{\mathrm{hi}}$ & $73.67^{\mathrm{fg}}$ & $78.53^{\mathrm{ab}}$ \\
150 & $136.3^{\mathrm{c}}$ & $140.3^{\mathrm{ab}}$ & $141.3^{\mathrm{a}}$ & $70.00^{\mathrm{h}}$ & $74.47^{\mathrm{ef}}$ & $79.53^{\mathrm{a}}$ \\
\hline
\end{tabular}

Means in columns and rows in each parameter followed by the same letter (s) are not significantly different from each other at $\mathrm{P}<0.05$. 
Without considering the effect of nitrogen rates, significantly longest leaf length was obtained from Intrarow spacing of $12.5 \mathrm{~cm}(56.39 \mathrm{~cm})$ which was $14.67 \%$ higher than the shortest leaf length observed at intra-row spacing of $7.5 \mathrm{~cm}$ (Table 3). The $10 \mathrm{~cm}$ spacing resulted in an intermediate leaf length which was statistically different from the other two intra-row spacing. The increase in leaf length of Improved Huruta shallot at wider spacing might be due to more nutrient and adequate spacing that permit the leaf to grow vigorously and hence, better growth of the crop. Many investigators including Ghaffoor et al., (2003) and Jilani et al., (2010). reported that maximum leaf length of onion was recorded in plants spaced at a wider spacing

\section{Yield and Yield Components}

\section{Bulb Diameter}

The analysis of variance revealed that the main effect of nitrogen and intra-row spacing had highly significant $(\mathrm{P}<0.01)$ influence on the bulb diameter of Improved Huruta shallot variety. However, the two factors interaction did not influence this parameter significantly (Table 9). Increasing the rate of nitrogen application consistently increased the bulb diameter of Improved Huruta shallot variety. Thus, the largest bulb diameter $(7.02 \mathrm{~cm})$ was recorded from the plant grown at the application of $125 \mathrm{~kg} \mathrm{~N} \mathrm{ha}^{-1}$ followed by $150 \mathrm{~kg} \mathrm{~N} \mathrm{ha}^{-1}$. This value was about $18.25 \%$ more than the smallest value obtained at zero nitrogen rates (Table 4). The development of wider bulb diameter of Improved Huruta shallot variety at higher nitrogen could be attributed to the availability of sufficient growth resource due to less competition that enable the bulb to accumulate more assimilates available for storage and result in higher bulb diameter. Nasreen et al. (2007) reported that increasing the rate of nitrogen significantly increased bulb diameter; indicating that nitrogen promotes growth of bulbs.

Regarding the main effect of intra row spacing, the widest bulb diameter was obtained from Intra-row spacing of $12.5 \mathrm{~cm}(6.84 \mathrm{~cm})$ which was $12.68 \%$ higher than the narrowest bulb diameter observed at intra-row spacing of $7.5 \mathrm{~cm}$ (Table 4). The wider bulb diameter of Improved Huruta shallot variety at wider spacing could be due less competition for moisture, nutrients and light at wider spacing that permit the bulb to accumulate more assimilates available for storage and result in higher bulb diameter. The current results are supported by the findings of Jilani et al. (2009) and Muhammad et al. (2011) who stated that higher bulb diameter was achieved for the wider plant spacing as compared to the closer spacing of onion.

\section{Bulb Length}

The main effect of nitrogen and intra-row spacing had significant $(\mathrm{P}<0.01)$ influence on the bulb length of Improved Huruta shallot variety. However, the two factors interaction did not influence this parameter (Table 9). Increasing the rate of nitrogen application consistently increased the bulb length of Improved Huruta shallot variety and the highest value $(6.45 \mathrm{~cm})$ was obtained from the application of $150 \mathrm{~kg} \mathrm{~N} \mathrm{ha}^{-1}$ followed by $125 \mathrm{~kg} \mathrm{~N} \mathrm{ha}^{-1}$ which was about $15 \%$ more than the lowest bulb length recorded from plants which did not receive nitrogen fertilizer (Table 5)
Table 3. Main effects of Nitrogen fertilizer rates and intra row spacing on leaf number per plant and leaf length of Improved Huruta shallot variety grown at Haramaya under rain fed and supplemental irrigation

\begin{tabular}{c|cc}
\hline Treatment & $\begin{array}{c}\text { Leaf number } \\
\text { per plant }\end{array}$ & $\begin{array}{c}\text { Leaf } \\
\text { length }(\mathrm{cm})\end{array}$ \\
\hline \multicolumn{3}{|c}{ Nitrogen kg Nha $^{-1}$} \\
\hline 0 & $7.07^{\mathrm{f}}$ & $47.62^{\mathrm{e}}$ \\
55 & $8.30^{\mathrm{e}}$ & $51.11^{\mathrm{d}}$ \\
75 & $8.67^{\mathrm{d}}$ & $52.58^{\mathrm{cd}}$ \\
100 & $8.91^{\mathrm{d}}$ & $53.33^{\mathrm{c}}$ \\
125 & $9.30^{\mathrm{c}}$ & $53.96^{\mathrm{bc}}$ \\
150 & $9.64^{\mathrm{b}}$ & $55.09^{\mathrm{ab}}$ \\
\multicolumn{3}{|c}{} \\
\hline 7.5 & $10.27^{\mathrm{a}}$ & $56.22^{\mathrm{a}}$ \\
10 & Spacing $(\mathrm{cm})$ \\
12.5 & $9.10^{\mathrm{c}}$ & $49.18^{\mathrm{c}}$ \\
\hline
\end{tabular}

Means within a Column followed by the same letter are not highly significantly different at $\mathrm{P}<0.05$.

Table 4. Main effect of nitrogen fertilizer rates and intra row spacing on bulb diameter of Improved Huruta shallot variety grown at Haramaya under rain fed and supplemental irrigation.

\begin{tabular}{|c|c|}
\hline Treatment & Bulb diameter $(\mathrm{cm})$ \\
\hline \multicolumn{2}{|c|}{ Nitrogen $\mathrm{kg} \mathrm{Nha}^{-1}$} \\
\hline 0 & $5.74^{\mathrm{f}}$ \\
\hline 25 & $6.08^{e}$ \\
\hline 50 & $6.37^{\mathrm{d}}$ \\
\hline 75 & $6.48^{\mathrm{cd}}$ \\
\hline 100 & $6.63^{b c}$ \\
\hline 125 & $7.02^{\mathrm{a}}$ \\
\hline 150 & $6.79^{b}$ \\
\hline \multicolumn{2}{|c|}{ Spacing $(\mathrm{cm})$} \\
\hline 7.5 & $6.07^{\mathrm{c}}$ \\
\hline 10 & $6.42^{\mathrm{b}}$ \\
\hline 12.5 & $6.84^{\mathrm{a}}$ \\
\hline
\end{tabular}

Means within a Column followed by the same letter are not significantly different at $\mathrm{P}<0.05$.

Table 5. The main effect of Nitrogen Fertilizer rates and intra row spacing on bulb length of Improved Huruta Shallot Variety grown at Haramaya under rain fed and supplemental irrigation

\begin{tabular}{c|c}
\hline Treatment & Bulb length $(\mathrm{cm})$ \\
\hline \multicolumn{3}{c}{ Nitrogen kg Nha- } \\
25 & $5.60^{\mathrm{e}}$ \\
50 & $5.86^{\mathrm{d}}$ \\
75 & $6.16^{\mathrm{c}}$ \\
100 & $6.23^{\mathrm{bc}}$ \\
125 & $6.30^{\mathrm{bc}}$ \\
150 & $6.42^{\mathrm{ab}}$ \\
\multicolumn{3}{c}{ Spacing (cm) } \\
\hline 7.5 & $6.45^{\mathrm{a}}$ \\
10 & $5.70^{\mathrm{c}}$ \\
12.5 & $6.14^{\mathrm{b}}$ \\
\hline
\end{tabular}

Means within a Column followed by the same letter are not significantly different at $\mathrm{P}<0.05$. 
In view of the independent effect of intra row spacing, the highest bulb length was obtained at the widest intra row spacing of $12.5 \mathrm{~cm}$ which was statistically different from intra row spacing of $10 \mathrm{~cm}$. On the other hand, the lowest bulb length was recorded from closest spacing of $7.5 \mathrm{~cm}$ which was statistically different from medium intra row spacing $(10 \mathrm{~cm})$ (Table 5). The increase in bulb length of Improved Huruta shallot variety at higher nitrogen rate and wider spacing might be attributed to reduced limitations of growth factors at wider spacing and higher nitrogen that allows luxurious foliage growth and the bulbs to have more assimilates available for storage and thus resulted in higher bulb length.

\section{Fresh and Dry Biomass Yield}

The fresh and dry biomass yield of Improved Huruta shallot variety were highly significantly $(\mathrm{P}<0.01)$ influenced by the main effect of nitrogen and intra-row spacing. However, the two factors interaction did not influence these parameters significantly (Table 9). The highest fresh biomass yield (132.8 $\left.\mathrm{g} \mathrm{plant}^{-1}\right)$ was obtained from the application of $125 \mathrm{~kg} \mathrm{~N}^{-1}$ followed by $150 \mathrm{~kg} \mathrm{~N}^{-1}$ which were greater by about 33.2 and $29.6 \%$, respectively, over the lowest fresh biomass yield recorded from plant fertilized with null nitrogen fertilizer application. Likewise plants supplied with Nitrogen at the rates $125 \mathrm{~kg} \mathrm{~N}^{-1}$ produced the highest dry total biomass yield while, the lowest values were obtained from plants which did not receive nitrogen fertilizer (Table 6).

Table 6. Main effect of Nitrogen fertilizer rates and intra row spacing on fresh and dry biomass yield of Improved Huruta shallot variety grown at Haramaya under rain fed and supplemental irrigation.

\begin{tabular}{c|cc}
\hline Treatment & $\begin{array}{c}\text { Fresh biomass } \\
\text { yield }\left(\mathrm{g} \mathrm{plant}^{-1}\right)\end{array}$ & $\begin{array}{c}\text { Dry biomass } \\
\text { yield }\left(\mathrm{g} \mathrm{plant}^{-1}\right)\end{array}$ \\
\hline \multicolumn{3}{c}{ Nitrogen kg Nha $^{-1}$} \\
\hline 0 & $99.70^{\mathrm{f}}$ & $24.72^{\mathrm{e}}$ \\
25 & $110.4^{\mathrm{e}} \mathrm{e}$ & $27.06^{\mathrm{d}}$ \\
50 & $117.1^{\mathrm{d}}$ & $29.63^{\mathrm{c}}$ \\
75 & $121.4^{\mathrm{cd}}$ & $31.87^{\mathrm{b}}$ \\
100 & $125.1^{\mathrm{bc}}$ & $32.96^{\mathrm{b}}$ \\
125 & $132.8^{\mathrm{a} a}$ & $35.86^{\mathrm{a}}$ \\
150 & $129.2^{\mathrm{a}}$ & $35.87^{\mathrm{a}}$ \\
\hline \multicolumn{3}{c}{} \\
\hline 7.5 & Spacing $(\mathrm{cm})$ & $21.89^{\mathrm{c}}$ \\
10 & $95.90^{\mathrm{c}}$ & $30.55^{\mathrm{b}}$ \\
12.5 & $120.40^{\mathrm{b}}$ & $40.97^{\mathrm{a}}$ \\
\hline
\end{tabular}

Means within a Column followed by the same letter are not significantly different at $\mathrm{P}<0.05$.

The increased fresh biomass yield of Improved Huruta shallot variety at higher nitrogen might be due to increased leaf growth and number which favored accumulation of more assimilates in the bulbs thereby increasing bulb length, diameter, and average bulb weight. Similarly, the increased dry biomass yield could be attributed to enhanced shoot and bulb production due to increased photo assimilation and dry matter accumulation. Similarly, the work of Nasreen et al. (2007) indicated that application of higher $\mathrm{N}$ doses increased dry total biomass yields of onion.

Without considering the effect of nitrogen rates, significantly highest fresh (141.8 g plant $\left.^{-1}\right)$ and dry (40.97 $\mathrm{g} \mathrm{plant}^{-1}$ ) biomass yield were obtained from Intra-row spacing of $12.5 \mathrm{~cm}$ respectively. On the other hand, the lowest fresh and dry biomass yield was recorded from plant supplied with no nitrogen application (plants in a control plots) (Table 6). The observed higher fresh and dry biomass per plant at wider intra-row spacing might be due to less competition for growth resources which enhanced luxurious foliage growth and consequently accumulation of biomass as compared to the plants grown at close spacing. The result is in line with Dereje et al. (2012) that reported that shallot bulbs planted at $20 \mathrm{~cm}$ intra-row spacing grow more vigorously and obtained more biological yield per plant than those planted at $10 \mathrm{~cm}$ spacing.

\section{Bulb Dry Matter}

The result from analysis of variance indicated that there was highly significant interaction $(\mathrm{P}<0.01)$ between nitrogen rate and intra row spacing on bulb dry matter content of Improved Huruta shallot variety (Table 9). With the increase in nitrogen rates and intra row spacing bulb dry matter increased significantly. Thus, the highest bulb dry matter $(16.9 \%)$ was recorded from plant supplied with nitrogen at $150 \mathrm{Kg} \mathrm{ha}^{-1}$ combined with $12.5 \mathrm{~cm}$ intra row spacing which is highly significant from the rest treatment combination (Table 7).

Average Bulb Weight

Average bulb weight of Improved Huruta shallot variety was highly significantly $(\mathrm{P}<0.01)$ affected due to the effect of applied nitrogen fertilizer at different rates, intra-row spacing and the interaction of the two factors (Table 9). Increasing the rate of nitrogen application progressively increased the average bulb weight of shallot across the increasing intra-row spacing. Thus, the highest average bulb weight $(116.87 \mathrm{~g}$ ) was recorded in response to the application of $125 \mathrm{~kg} \mathrm{~N} \mathrm{ha}^{-1}$ and intra-row spacing of $12.5 \mathrm{~cm}$, which was $131 \%$ more than lowest bulb weight recorded from plants that did not receive nitrogen fertilizer and planted at intra-row spacing of $7.5 \mathrm{~cm}$. But, further increase to $150 \mathrm{~kg} \mathrm{~N} \mathrm{ha}^{-1}$ did not increase average bulb weight (Table 7).

The increment in bulb size with the amount of applied $\mathrm{N}$ is attributed to the increase in plant height, number of leaves produced, leaf length, and extended physiological maturity, which increased assimilate production and partitioning to the bulbs. Similarly, the increment in bulb size at lower number of plants could be due to the fact that wider spacing accommodates less number of plants which received adequate growth resources and helped to increase the average weight of bulb per plant. Similarly, Dereje et al. (2012) with shallots and Mahadeen, (2008), Jilani et al. (2010) and Muhammad et al. (2011) with onion also reported average bulb weight increased with decreasing plant population.

The increased dry bulb matter at increased application of nitrogen and widest intra row spacing is due to the fact that nitrogen is the most limiting factor in crop production including shallot and application of $\mathrm{N}$ fertilizer results in higher biomass yields. Similarly, wider spacing resulted in less competition for growth resources, thus increased amount of assimilate produced. On the other hand, the lowest bulb dry weight $(7.27 \%$ ) was recorded from plants that received nil nitrogen rate combined with $7.5 \mathrm{~cm}$ intra row spacing. This might be due to the fact that closer 
spacing resulted in high competition for growth resources, thus reducing amount of assimilate produced and stored in the bulbs which reduced their bulb weight. In line with the present study Kumar et al. (1998) and Yadav et al. (2003) reported that the highest bulb dry weight of onion was obtained at the rate of $150 \mathrm{~kg} \mathrm{~N} \mathrm{ha}^{-1}$. Likewise Sikder et al. (2010) explained that higher bulb dry weight was achieved in wider spacing in onion plants.

\section{Marketable Bulb Yield}

The results from analysis of variance revealed that the main effect of nitrogen as well as that of intra-row spacing had highly significant $(\mathrm{P}<0.01)$ influence on the marketable bulb yield of the Improved Huruta shallot variety. However, the interaction effect of nitrogen application and intra-row spacing was not significantly influenced the marketable bulb yield of the crop (Table 9). Increasing the rate of nitrogen application until $125 \mathrm{~kg} \mathrm{~N}$ $\mathrm{ha}^{-1}$ significantly increased the production of marketable bulb yield. Thus, the highest marketable bulb yield was recorded from plants grown at the rate of $125 \mathrm{~kg} \mathrm{~N}$ ha ${ }^{1}$ which was $40.80 \%$ higher yield than the lowest marketable bulb yield recorded from plants grown with zero nitrogen. But, further increase of $\mathrm{N}$ rates beyond 125 $\mathrm{kg} \mathrm{N} \mathrm{ha}^{-1}$ did not increase the yield (Table 8). The increased marketable yield at the increased rate of nitrogen fertilizer might be associated with optimum supply of $\mathrm{N}$ in the soil. A similar result was obtained by Biru (2015) who reported that application of $\mathrm{N}$ increased the total and marketable bulb yields as compared to the untreated control.

Irrespective of the main effect of nitrogen, the highest marketable bulb (50.25 $\left.\mathrm{t} \mathrm{ha}^{-1}\right)$ was recorded from plants grown at $7.5 \mathrm{~cm}$ intra row spacing which was $32.83 \%$ more than the lowest marketable bulb yield recorded from 12.5 $\mathrm{cm}$ intra row spacing (Table 8). The increased marketable yield at the closest spacing might be associated with higher number of plant population per unit area which leads to maximum number of bulbs with relatively less competition. The higher bulb size under wider spacing did not compensate for the reduction in yield per hectare caused by decreased plant population at wider spacing. The result is in line with the report of Dereje et al. (2012) and Kahsay et al. (2013) who explained higher marketable bulb yield was obtained from closest spacing as compared to plant spaced at wider spacing.

Unmarketable Bulb Yield

The unmarketable bulb yield of the Improved Huruta shallot variety was highly significantly $(\mathrm{P}<0.01)$ influenced by the main effect of nitrogen as well as that of intra-row spacing. However, the interaction effect of nitrogen application and intra-row spacing did not influence the unmarketable bulb yield of the crop (Table 9). With the increase in the nitrogen fertilizer rate, unmarketable bulb yield of Improved Huruta shallot variety decreased significantly. Thus, the highest value of unmarketable bulb yield $\left(4.88 \mathrm{t} \mathrm{ha}^{-1}\right)$ was recorded in plant grown without nitrogen fertilizer (Table 8).

The higher unmarketable yield at lower nitrogen application rates might be associated with more competition for growth resources and shortage of nitrogen for proper growth and development of every plant in the stand. In contrast, the lowest unmarketable bulb yield $\left(2.66 \mathrm{t} \mathrm{ha}^{-1}\right)$ was recorded when Improved Huruta shallot variety were fertilized with $150 \mathrm{~kg} \mathrm{~N}^{-1}$ followed by $125 \mathrm{kgNha}^{-1}$. The lower unmarketable yield in higher rate of nitrogen might be attributed to less competition for growth resources which results in larger bulbs which increased the proportion of marketable bulb yield of Improved Huruta shallot variety. This might be ascribed mainly to nitrogen deficiency and sub-optimal growth of plants which in turn resulted in weaker plants prone to disease and other biotic and abiotic stresses as well as low assimilate produced, resulting in lower size of bulbs (Kahn et al., 2002).

Similarly, with the increase in the intra-row spacing, unmarketable bulb yield of Improved Huruta shallot variety decreased significantly. The highest unmarketable yield was recorded from plant spaced at $7.5 \mathrm{~cm}$ intra row spacing which was $80.6 \%$ higher than the lowest value measured from plant grown at $12.5 \mathrm{~cm}$ intra row spacing (Table 8). The higher unmarketable yield at closest spacing could be due to intra-plant competition for growth resources which resulted in relatively lower proportion of large sized bulbs than wider spacing. The results are in accord with those of Yemane et al. (2014) and Dereje et al. (2012) who mentioned that narrow intra-row spacing increased unmarketable bulb yield of onion and shallot respectively.

\section{Total Bulb Yield}

The analysis of variance indicated that the main effect of nitrogen as well as that of intra-row spacing was highly significantly $(\mathrm{P}<0.01)$ influenced the total bulb yield of the Improved 'Huruta' shallot variety. However, the interaction effect of nitrogen fertilizer rates and intra-row spacing did not influence the total bulb yield of the crop (Table 9).

Table 7. Interaction effect of nitrogen fertilizer rates and intra row spacing on average bulb weight and bulb dry weight of Improved Huruta shallot variety grown at Haramaya under rain fed and supplemental irrigation.

\begin{tabular}{c|cccccc}
\hline \multirow{2}{*}{ Treatment } & \multicolumn{4}{c}{ Parameter } \\
\cline { 2 - 6 } & \multicolumn{3}{|c}{$\begin{array}{c}\text { Average bulb weight }(\mathrm{g}) \\
\text { Intra-row spacing }(\mathrm{cm})\end{array}$} \\
\hline $\mathrm{N}$ rate $\left(\mathrm{kg} \mathrm{ha}^{-1}\right)$ & 7.5 & 10 & 12.5 & \multicolumn{3}{c}{$\begin{array}{c}\text { Bulb dry matter }(\%) \\
\text { Intra-row spacing }(\mathrm{cm})\end{array}$} \\
0 & $50.53^{\mathrm{m}}$ & $61.97^{\mathrm{l}}$ & $71.43^{\mathrm{k}}$ & $7.27^{\mathrm{q}}$ & $8.43^{\mathrm{nop}}$ & 12.5 \\
25 & $61.07^{\mathrm{l}}$ & $71.57^{\mathrm{k}}$ & $85.13^{\mathrm{i}}$ & $7.73^{\mathrm{pq}}$ & $8.87^{\mathrm{mn}}$ & $11.87^{\mathrm{fg}}$ \\
50 & $71.83^{\mathrm{k}}$ & $81.40^{\mathrm{j}}$ & $94.80^{\mathrm{g}}$ & $8.01^{\mathrm{opq}}$ & $9.43^{\mathrm{klm}}$ & $12.87^{\mathrm{de}}$ \\
75 & $81.93^{\mathrm{j}}$ & $91.70^{\mathrm{h}}$ & $104.17^{\mathrm{d}}$ & $8.67^{\mathrm{mno}}$ & $9.73^{\mathrm{kl}}$ & $13.50^{\mathrm{d}}$ \\
100 & $90.50^{\mathrm{h}}$ & $101.10^{\mathrm{e}}$ & $110.23^{\mathrm{bc}}$ & $9.13^{\mathrm{lmn}}$ & $11.33^{\mathrm{gh}}$ & $14.60^{\mathrm{c}}$ \\
125 & $98.77^{\mathrm{ef}}$ & $110.80^{\mathrm{b}}$ & $116.87^{\mathrm{a}}$ & $9.97^{\mathrm{jk}}$ & $12.20^{\mathrm{ef}}$ & $15.77^{\mathrm{b}}$ \\
150 & $96.57^{\mathrm{fg}}$ & $107.67^{\mathrm{c}}$ & $114.03^{\mathrm{a}}$ & $10.87^{\mathrm{hi}}$ & $12.97^{\mathrm{d}}$ & $16.90^{\mathrm{a}}$ \\
\hline
\end{tabular}

Means within a Column and rows followed by the same letter are not significantly different at $\mathrm{P}<0.05$. 
Table 8. Main effect of nitrogen fertilizer rates and intra row spacing on marketable bulb yield, unmarketable bulb yield and total bulb yield of Improved Huruta shallot variety grown at Haramaya under rain fed and supplemental irrigation

\begin{tabular}{|c|c|c|c|}
\hline Treatment & $\begin{array}{c}\text { Marketable bulb } \\
\text { yield }\left(\mathrm{t} \mathrm{ha}^{-1}\right)\end{array}$ & $\begin{array}{l}\text { Unmarketable bulb } \\
\text { Yield }\left(\mathrm{t} \mathrm{ha}^{-1}\right)\end{array}$ & $\begin{array}{l}\text { Total bulb } \\
\text { Yield }\left(\mathrm{t} \mathrm{ha}^{-1}\right)\end{array}$ \\
\hline \multicolumn{4}{|c|}{ Nitrogen $\mathrm{kg} \mathrm{ha}^{-1}$} \\
\hline 0 & $37.92^{\mathrm{e}}$ & $4.88^{\mathrm{a}}$ & $42.81^{\mathrm{e}}$ \\
\hline 25 & $40.35^{\mathrm{d}}$ & $4.56^{\mathrm{ab}}$ & $44.92^{\mathrm{d}}$ \\
\hline 50 & $41.76^{\mathrm{d}}$ & $4.23^{\mathrm{bc}}$ & $45.98^{\mathrm{d}}$ \\
\hline 75 & $44.32^{\mathrm{c}}$ & $4.00^{\mathrm{cd}}$ & $48.32^{\mathrm{c}}$ \\
\hline 100 & $47.99^{\mathrm{b}}$ & $3.67^{\mathrm{de}}$ & $51.38^{\mathrm{b}}$ \\
\hline 125 & $53.39^{\mathrm{a}}$ & $3.31^{\mathrm{e}}$ & $56.70^{\mathrm{a}}$ \\
\hline 150 & $48.72^{\mathrm{b}}$ & $2.66^{\mathrm{f}}$ & $51.66^{\mathrm{b}}$ \\
\hline \multicolumn{4}{|c|}{ Spacing $(\mathrm{cm})$} \\
\hline 7.5 & $50.25^{\mathrm{a}}$ & $4.75^{\mathrm{a}}$ & $55.00^{\mathrm{a}}$ \\
\hline 10 & $46.68^{\mathrm{b}}$ & $4.32^{\mathrm{b}}$ & $51.01^{\mathrm{b}}$ \\
\hline 12.5 & $37.83^{\mathrm{c}}$ & $2.63^{c}$ & $40.46^{\mathrm{c}}$ \\
\hline
\end{tabular}

Means within a Column followed by the same letter are not significantly different at $\mathrm{P}<0.05$.

Table 9. Mean squares from analysis of variance for bulb yield and yield components of Improved Huruta shallot variety as influenced by nitrogen fertilizer and intra-row spacing at Haramaya in 2017

\begin{tabular}{|c|c|c|c|c|c|c|}
\hline Parameter & $\begin{array}{c}\text { Replication } \\
(2)\end{array}$ & $\begin{array}{l}\text { Nitrogen } \\
(\mathrm{N})(6)\end{array}$ & $\begin{array}{l}\text { Intra-row spacing } \\
(\mathrm{cm})(\mathrm{S})(2)\end{array}$ & $\begin{array}{c}\mathrm{N} \times \mathrm{S} \\
(12) \\
\end{array}$ & $\begin{array}{l}\text { Error } \\
(40) \\
\end{array}$ & $\begin{array}{l}\mathrm{CV} \\
(\%) \\
\end{array}$ \\
\hline Days to maturity & 25.48 & $75.86 * *$ & $337.47 * *$ & $1.83^{*}$ & 0.74 & 1.0 \\
\hline Plant height $(\mathrm{cm})$ & 48.91 & $401.386^{* *}$ & $334.476 * *$ & $3.57 *$ & 1.64 & 1.2 \\
\hline Leaf number & 0.1644 & $6.363 * *$ & $14.8768 * *$ & 0.0531 & 0.1318 & 4.0 \\
\hline Leaf length $(\mathrm{cm})$ & 1.315 & $72.401 * *$ & $273.09 * *$ & 0.97 & 2.797 & 3.2 \\
\hline Bulb diameter $(\mathrm{cm})$ & 0.29992 & $1.67591 * *$ & $3.07808 * *$ & 0.06035 & 0.03744 & 3.2 \\
\hline Bulb length (cm) & 0.08658 & $0.86811 * *$ & $4.33504 * *$ & 0.01269 & 0.03827 & 3.0 \\
\hline Fresh biomass yield (g plant ${ }^{-1}$ ) & 1082.84 & $1177.87 * *$ & $11074.04 * *$ & 17 & 21.16 & 3.9 \\
\hline Dry biomass yield $\left(\mathrm{g}\right.$ plant $\left.^{-1}\right)$ & 123.47 & $162.81 * *$ & $1915.85^{* *}$ & 5.94 & 4.65 & 6.9 \\
\hline Average bulb weight (g) & 81.389 & $2861.775^{* *}$ & $2267.936 * *$ & $8.474 * *$ & 3.080 & 2.0 \\
\hline Bulb dry matter $(\%)$ & 0.7521 & $27.1967 * *$ & $131.6401 * *$ & $0.8038 * *$ & 0.1923 & 4.0 \\
\hline Marketable bulb yield $\left(\mathrm{t} \mathrm{ha}^{-1}\right)$ & 51.671 & $263.659 * *$ & $859.218 * *$ & 5.402 & 3.543 & 4.2 \\
\hline Unmarketable bulb yield $\left(\mathrm{t} \mathrm{ha}^{-1}\right)$ & 6.189 & $5.194 * *$ & $26.4033 * *$ & 0.2239 & 0.2533 & 12.9 \\
\hline Total bulb yield $\left(\mathrm{t} \mathrm{ha}^{-1}\right)$ & 32.502 & $204.594 * *$ & $1185.587 * *$ & 5.34 & 3.673 & 3.9 \\
\hline
\end{tabular}

*and**, significant at $\mathrm{P}<0.05$ and $\mathrm{P}<0.01$, respectively. Numbers in parenthesis in each source of variation represents degree of freedom.

Similar to the marketable bulb yield, the highest total bulb yield of Improved Huruta shallot variety was recorded from plants grown at the rate of $125 \mathrm{~kg} \mathrm{~N} \mathrm{ha}^{-1}$ which was $32.45 \%$ higher than the lowest bulb yield recorded from plants that were supplied with zero application of nitrogen followed by 25 and $50 \mathrm{~kg} \mathrm{~N}^{-1}$ (Table 8). Therefore, using $125 \mathrm{~kg} \mathrm{~N} \mathrm{ha}^{-1}$ is the most optimum dose for Improved Huruta shallot for marketable and total bulb yield production. In line with the present result, Balemi et al. (2007) also observed a significant increase in total bulb yield in response to increased application rate of nitrogen.

In view of the main effect of intra row spacing, the highest total bulb yield $\left(55.00 \mathrm{t} \mathrm{ha}^{-1}\right)$ of Improved Huruta shallot variety was recorded from plants grown at the narrowest spacing $(7.5 \mathrm{~cm})$ which was highly significantly different from the lowest total bulb yield recorded from $12.5 \mathrm{~cm}$ intra row spacing (Table 8 ). The increased total bulb yield by high plant population could be explained due to the increased in number of plant in the stand and consequently resulted in higher number of bulbs produced per unit area. Similar result was reported by Dereje et al. (2012) who indicated that total bulb yield decreased with increase in the intra-row spacing of shallot.

\section{Conclusion}

In this study, the application of $125 \mathrm{~kg} \mathrm{~N} \mathrm{ha}^{-1}$ gave high total and marketable bulb yield advantage of $32.45 \%$ $\left(13.89 \mathrm{t} \mathrm{ha}^{-1}\right)$ and $40.8 \%\left(15.47 \mathrm{tha}^{-1}\right)$ respectively over the control. Plants spaced at $7.5 \mathrm{~cm}$ had total and marketable bulb yield advantage of $35.94 \%$ (14.54 $\left.\mathrm{t} \mathrm{ha}^{-1}\right)$ and $32.83 \%$ $\left(12.42 \mathrm{t} \mathrm{ha}^{-1}\right)$, respectively over plants spaced at $12.5 \mathrm{~cm}$. Therefore, it is possible to conclude that intra-row spacing of $7.5 \mathrm{~cm}$ with the application of $125 \mathrm{~kg} \mathrm{~N} \mathrm{ha}^{-1}$ could be used for the production of Improved 'Huruta' shallot variety around Haramaya. However, for the large scale cultivation in eastern Ethiopia, the experiment should be repeated over seasons and locations on farmers' field and research stations.

\section{References}

Ademe D, Belew D, Tabor G. 2012. Influence of bulb topping and intra row spacing on yield and quality of some shallot (Allium Cepa Var. Aggregatum) varieties at Aneded woreda, western Amhara. African Journal of Plant Science, 6(6): 90-202.

Balemi T, Pal N, Saxena A. 2007. Response of onion (Allium cepa L.) to combined application of biological and chemical nitrogenous fertilizers. Acta Agriculturae Slovenica, 89(1), p.107. 
Belay SC, Wortman W, Hoogen G. 1998. Haricot bean agroecology in Ethiopia: definition using agro-climatic and crop growth stimulation models. African Crop Science Journal, 6 (1): 9-18.

Biru FN. 2015. Effect of spacing and nitrogen fertilizer on the yield and yield component of shallot (Allium ascalonium L.). Journal of Agronomy, 14(4): p.220.

Bodnar J. 2010. Fact sheet: Shallots: What they are and how to grow them. Ministry of agriculture food and rural affairs, Ontario. Queen's printer for Ontario: ISSN.

Brewster J. 1994. Onions and other vegetable Alliums. 236 pp. Wellesbourne. Hort. Res. Internat.

Brewster JL. 1994. Onions and other vegetable Alliums. $2^{\text {nd }}$ edition. CABI Publishing, Wallingford, UK.

Burga S, Dechassa N, Tsegaw T. 2014. Influence of mineral nitrogen and potassium fertilizers on ware and seed potato production on alluvial soil in Eastern Ethiopia. East African Journal of Sciences, 8(2): 155-164.

Currah L, Proctor FJ. 1990. Onions in tropical regions. Overseas Research and Development Administration, Natural Resource Institute (No. 35).

Desalegn L, Aklilu S. 2003. Research experiences in onions production. Research Report Number, 55, EARO, Addis Ababa, Ethiopia.

Devi AK, Anal L. 2008. Yield and economic response of multiplier onion (Allium cepa L. var aggregatium Don.) to agronomic management under Manipur condition. J. Environ. Ecol, 26(4): 44-48.

EIAR (Ethiopian Institutes of Agricultural Research). 2004 Directory of released crop Varieties and their recommended cultural practices. Addis Ababa, Ethiopia.

Ghaffoor A, Jilani MS, Khaliq G, Waseem K. 2003. Effect of different NPK levels on the growth and yield of three onion (Allium cepa L.) varieties. Asian Journal of Plant Sciences, 2(3): 342-346.

Grubben GJH, Denton OA. 2004. Plant Resources of Tropical Africa 2. Vegetables. PROTA Foundation, Wageningen, Netherlands. backhuys Publishers, Leiden, Netherlands/ CTA, Wgeningen Netherlands. Http://www/hort. purdue/ edu/newcrop.duke_energy/moringa.htm. Accessed on, 4(05), p.2008.

Jilani MS, Ahmed P, Waseem K, Kiran M. 2010. Effect of plant spacing on growth and yield of two varieties of onion (Allium cepa L.) under the agro-climatic condition of DI Khan. Pakistan Journal of Science, 62(1): 37-41.

Jilani MS, Khan MQ, Rahman S. 2009. Planting densities effect on yield and yield components of onion (Allium cape L.). Journal of Agricultural Research, 47(4): 397-404.

Kahsay Y. Abay F, Belew D. 2013. Intra row spacing effect on shelf life of onion varieties (Allium cepa L.) at Aksum, Northern Ethiopia. Journal of Plant Breeding and Crop Science, 4(6): 127-136.

Khan H, Iqbal M, Ghaffoor A, Waseem K. 2002. Effect of various plant spacing and different nitrogen levels on growth and yield of onion (Allium cepa L.). J. Biol. Sci, 2(8): 545-547.
Kumar H, Singh J.V, Kumar A, Singh M. 1998. Studies on the effect of spacing on growth and yield of onion (Allium cepa L) Cv'Patna Red'. Indian Journal of Agricultural Research, 32(2): 134-138.

Mahadeen AY. 2008. Effect of planting date and plant spacing on onion (Allium cepa. L) yield under rain fed in semi-arid conditions of Jordan bull. Faculty of Agriculture Cairo University, 59: 237-241.

Marschner H. 1995. Mineral Nutrition of higher plants. $2^{\text {nd }}$ Edition. Academic Press, London, UK.

Mohammed W, Woldetsadik K, Kebede B. 2017. Multilocation yield trial of shallot (Allium cepa var. ascalonicum Backer) and onion (Allium cepa L.) varieties in eastern Ethiopia. In: $34^{\text {th }}$ Annual Research Proceedings, Theme I: Productivity and Environmental Sustainability for Food Security and Poverty Alleviation, Haramaya University. Volume I, pp. 191-207.

Muhammad A, Gambo BA, Ibrahim ND. 2011. Response of onion (Allium cepa L.) to irrigation intervals and plant density in Zuru, Northern Guinea Savanna of Nigeria. Nigerian Journal of Basic and Applied Science, 19(2): 241247.

Nasreen S, Haque M M, Hosai MA, Farid ATM. 2007. Nutrient uptake and yield of onions as influenced by nitrogen and sulphur fertilization. Bangladesh Journal of Agricultural Resources, 32(3): 413-420.

Purba R. 2014. Applications of NPK Phonska and KCl Fertilizer for the Growth and Yield of Shallots (Allium Ascalonicum) in Serang, Banten. International Journal of Applied Science and Technology, 4(3): 197-203.

Rao BN, Roy SS, J ha AK, Singh IM, Prakash N. 2013. Influence of nitrogen and spacing on the performance of Alliuodorosumunder mid-altitude foothill condition of Manipur. Indian Journal of Hill Farming, 26(2): 67-70.

Sikder M, Mondal F, Mohammed D, Alam MS, Amin MB. 2010. Effect of spacing and depth of planting on growth and yield of onion. Journal of Agroforestry and

Singh BB, Raj DM, Dashiell KE, Jackai LEN. 1997. Advances in cowpea research, co publication of international institute of tropical agriculture (IITA) and Japan international research center for agricultural sciences (JIRCAS), IITA, Ibadan, Nigeria. Ibadan Nigeria. IITA. JIRCAS.

Singh JV, Kumar A, Singh C. 2000. Influence of phosphorus on growth and yield of onion (Allium cepa L.). Indian Journal of Agricultural Research, 34(1): 51-54.

Subbo-Rao. 1988. Bio-fertilizers in agriculture. Oxford and TBH Pub. Co. Ltd. New Delhi, Bombay, Calcutta.

Williams CN, Ozo JO, Peregrine WTH. 1991. Vegetable production in the tropics. Longman UK. Intermediate Tropical Agricultural Series, 144.

Woldetsadik K. 2003. Shallot (Allium cepa var. ascolonicum) responses to plant nutrients and soil moisture in a sub-humid tropical climate (Doctoral dissertation, Swedish University of Agricultural Sciences).

Yadav RL, Sen NL, Yadav BL. 2003. Response of onion to nitrogen and potassium fertilization under semi-arid condition. Indian Journal Horticulture, 60(2):176-178 